DOI: https://doi.org/10.15407/techned2019.06.005

\title{
ELECTROMAGNETIC FIELD OF W-SHAPED INDUCTOR FOR MAGNETIC-PULSE PROCESSING OF MATERIALS
}

\author{
Journal \\ Publisher \\ ISSN \\ Issue
}

Pages

\author{
Tekhnichna elektrodynamika \\ Institute of Electrodynamics National Academy of Science of Ukraine \\ 1607-7970 (print), 2218-1903 (online) \\ No 6, 2019 (November/December) \\ $5-12$
}

\author{
Authors \\ A.P. Rashchepkin*, I.P. Kondratenko**, A.N. Karlov ${ }^{\star \star \star}$, R.S. Kryshchuk ${ }^{\star \star \star \star}$ \\ Institute of Electrodynamics National Academy of Sciences of Ukraine, \\ pr. Peremohy, 56, Kyiv, 03057, Ukraine, \\ e-mail: anatoly_raschepkin@ukr.net, dep7ied@ukr.net, lexa.k.ua@gmail.com, \\ kr@nas.gov.ua \\ * ORCID ID : http://orcid.org/0000-0002-3308-8032 \\ ** ORCID ID : http://orcid.org/0000-0003-1914-1383 \\ *** ORCID ID : http://orcid.org/0000-0002-1350-1870 \\ **** ORCID ID : http://orcid.org/0000-0002-1933-0144
}

\begin{abstract}
The method of analysis of electromagnetic processes in an inductor with a W-shaped ferromagnetic core is presented. The inductor is designed for contactless excitation in any metal plate of magnetic field pulses and high density currents. The inductor magnetic core has a movable middle part for an additional pulsed physical impact on the metal plate. Thus, the action of the inductor is for achieving a magnetoplastic effect (MPE) in metal plates with plastic deformation. Current pulses in the winding of the inductor are performed by discharging a capacitor on the circuit. A thyristor is included in the inductor circuit, which makes it possible to obtain unipolar current pulses in the inductor winding. Parallel to the capacitor, a diode is included, which makes it possible to obtain unipolar, but slowly decaying current pulses in the winding. The electrical parameters of the inductor are determined by computer simulation for a quasi-stationary mode using the finite element method for the set of current values. It takes into account the magnetization curve of the magnetic core. The transient current is determined from the solution of the nonlinear differential equation of the electrical circuit. The current allows us to
\end{abstract}


solve the transient electromagnetic problem in a metal plate using the finite element method. The conditions for obtaining a unipolar pulsed electromagnetic field in a metal plate are investigated. The method in this article is used for calculation electromagnetic problems in the inductor with magnetic core $164 \times 100 \times 33 \mathrm{~mm}$. Magnetic forces which acting on the movable part of the magnetic circuit and on the metal plate is obtained. References 11, figures 6.

Key words: inductor, magnetoplastic effect, plastic deformation, pulsed eddy current, electromagnetic field.

Received: 29.03.2019

Accepted: 02.07.2019

Published: 25.10.2019

\section{References}

1. Vasilev M.A. Features of plastic deformation of metals and alloys in a magnetic field.

Overview. Uspekhi fiziki metallov. 2007. Vol. 8. Pp. 65-105. (Rus) DOI: https://doi.org/10.1540 7/ufm.08.01.065

2. Kuznetsov N.N. Influence of electro impulse and magneto impulse effects on the workpiece. Obrabotka materialov davleniem

. 2010. No 3(24). Pp. 126-129. (Rus)

3. Komshina A.V., Pomelnikova A.S. Promising method of low-energy materials processing using a magnetic field. Nauchnoe izdanie MGTU im. N.E. Baumana. Nauka i Obrazovanie. 2012. No FS77 - 48211. Pp. 463-488. DOI:

https://doi.org/10.7463/0912.0454270 (Rus)

4. Samohvalov V.N., Samohvalova Zh.V. Magnetic-pulse and electric pulse treatment of machine parts. Sovremennye problemy teorii mashin. 2017. No 5. Pp. 113-115. (Rus)

5. Seidametov S.V., Loskutov S.V. The influence of pulse electromagnetic field on rebuilding of structure of titanium alloy VT3-1. Zhurnal fizyky ta inzhenerii poverkhni. 2016. Vol. 1. Pp. 4-8.

(Rus)

6. Golovin Yu.I., Morgunov R.B. New type of magnetoplastic effects in linear amorphous polymers. Fizika tverdogo tela. 2001. Vol. 43(5). Pp. 827-832. (Rus) DOI: https://doi.org/10.11 34/1.1371366

7. Nejman L.R., Demirchyan K.S. Theoretical foundations of electrical engineering. Moskva-Leningrad: Energiia, 1966. 407 p. (Rus)

8. Postnikov I.M. Electrical machinery design. Kiev: Gosudarstvennoe izdanie tekhnicheskoi literatury USSR, 1962. 736 p. (Rus) 
9. Lobanov L.M., Kondratenko I.P., Zhyltsov A.V., Karlov O.M., Pashchyn M.O., Vasyuk V.V., Yashchuk V.A. Electrophysical unsteady processes in the system to reduce residual stresses welds. Tekhnichna Elektrodynamika. 2016. No 6. Pp.10-19. DOI: https://doi.org/10.15407/tech ned2016.06.010

10. Comsol multiphysics modeling and simulation software. URL: http://www.comsol.com/ 11. Kondratenko I.P., Zhyltsov A.V., Pashchyn N.A., Vasyuk V.V. Selecting induction type electromechanical converter for electrodynamic processing of welds. Tekhnichna Elektrodynamika 2017. No 5. Pp. 83-87. DOI:

https://doi.org/10.15407/techned2017.05.083 (Ukr)

PDF 